Int. J. Speleol. 14 (1984-1985), pp. 39-50

\title{
Two new genera of cave-dwelling millipedes (Diplopoda), with remarks on the millipede fauna of West Caucasian caves
}

\author{
Sergei I. Golovatch *
}

SUMMARY

Two new genera and species of the Diplopoda from Caucasian caves are described: troglobitic Caucasodesmus inexpectatus n.g., n.sp. (family Macrosternodesmidae) from a cave in North Osetia, North Caucasus, and troglophilic Ratcheuma excorne n.g., n.sp. (family Antroleucosomatidae) from a cave in Racha, Georgia, Transcaucasia. Millipedes of the western Caucasian cavernicolous fauna are reviewed as regards their distribution, relationship with caves and zoogeographical connections.

Millipedes are quite common in caves of all geographical zones, but the USSR cavernicolous diplopod fauna is still very poorly known. Only 12 species and 1 subspecies of the myriapods have hitherto been registered in Transcaucasian caves (Verhoeff, 1930; Lohmander, 1936; Strasser, 1970; Golovatch, 1975,1976 , 1983, two or three forms of them being possible troglobites.

A general aspect of both terricolous and cavernicolous millipedes of the Caucasus is Ancient Mediterranean; the only exception is the oriental genus Hyleoglomeris with several Caucasian endemic species, one of which has been recorded so far

* Institute of Evolutionary Morphology \& Ecology of Animals, USSR Academy of Sciences, Moscow V-71, Leninsky prospekt 33, USSR. 
only in a cave in the Mountanous Karabakh, Soviet Azerbaijan (Golovatch, 1975). All the more interesting seem the finds of two new genera and species of diplopods from Caucasian caves displaying, along with many other cavernicolous invertebrates of this region (Birstein, Ljovuschkin, 1967), Ancient Mediterranean faunal connections. The holotypes and paratypes of the forms described herein are deposited in the collection of the Zoological Museum of the Moscow State University, Moscow. USSR.

\section{Caucasodesmus gen.n.}

Body small (less than $1 \mathrm{~cm}$ ), of 19 segments. Antennae long and slender; article 6, the largest one, with a dorso-distal group of ca. ten bacilli. Body rings are very convex on the dorsum, without lateral keels, but with distinct lateral swellings provided with dentate margin; 3 transverse rows of several long setae on terga. Pore formula normal. Sculpture very poorly developed.

Gonopods consist of quite globose coxites fused medially. No sign of coxal horns (cannulae). Telopodite small; the prefemoral portion rather elongated, more or less transverse and forming a right angle with the acropodite; telopodites in situ held approximately parallel, without a trace of seminal groove, divided distally into two distinct branches.

Type species: Caucasodesmus inexpectatus sp.n.

Caucasodesmus n.g. is a most peculiar representative of the order Polydesmida. Aside from the new form, simultaneous loss of both coxal horns and seminal groove of gonopods is met with only in the rhachodemid genus Atopogonus Carl from New Caledonia (Carl, 1926); however, the loss seems to have occurred in the two genera quite independently.

Another peculiarity of Caucasodesmus n.g. is a somewhat intermediate position between members of the families Trichopolydesmidae s. str. and Macrosternodesmidae. Judging from the quite globose gonocoxae and certain external features, Caucasodesmus n.g. may be treated related to Trichopolydesmus Verh., Bacillidesmus Att. and Napocodesmus Ceuca from SE Europe. The two latter genera were formerly placed within the independent family Bacillidesmidae, but an apparently close relationship of bacillidesmids with Trichopolydesmus resulting in the family Trichopolydesmidae s.str. (Hoffman, 1979) seems to exist. More expressed is the relationship of Caucasodesmus n.g. with a group of genera (Macrosternodesmus Broel., Ophiodesmus Cook, Verhoeffodesmus Str. from W Europe as well as Chaetaspis Boll. and some other "nearctodesmids" from the 
Nearctic) characterized by transverse gonoprefemora forming a right angle with the acropodite, both the latters holding more or less parallel in situ, namely with the family Macrosternodesmidae (Hoffman, 1979, in press). Caucasodesmus n.g. is therefore an aberrant Caucasian relic of probably Ancient Mediterranean genesis; anyway, the Caucasus seems to be the known easternmost outpost for the trichopolydesmid \& macrosternodesmid phyletic line.

Caucasodesmus inexpectatus sp.n.

\section{Material}

Caucasus, N Osetia. ca. $25 \mathrm{~km} \mathrm{SW}$ of Ordzhonikidze, right bank of the Fiagdon River, ca. $2 \mathrm{~km}$ from the village Tagardon, Cave Nyvdjinlagat: $5 \delta^{\top} \delta^{\pi}, 1$ juv. - 5. XI 1971, leg. S. I. Ljovuschkin, B. P. Chevrizov.

The only unbroken specimen, male holotype ( $p$ 1525), ca. $7,5 \mathrm{~mm}$ long and $0.55 \mathrm{~mm}$ wide. 19 body segments. Body colour uniformly whitish. Head densely pubescent at the anterior part Labrum with one medial tooth at the anterior margin. Gnathochilarium without peculiarities. Antennae (fig. 1; 1) very long and slender, densely setose; article 6, the largest one, dorsodistally with a compact group of some ten bacilli. Body moniliform, slender, with parallel sides, abruptly narrowing at the body ring 18 . Head considerably broader than the ellipsoid collum, a little broader than the body segment 2 and as wide as the 3rd ring. Each tergite bears 3 transverse rows of several rather long acute bacillary setae situated on small tubercles. Pore formula $5,7,9,10,12,13,15-18$. On every segment there are evident small lateral projectons dentate at the margin; on pose-bearing rings the projections, the hinder parts of which are directed somewhat obliquely dorsally, are considerably better developed (fig. 1; 2). Tergite sculpture nearly not expressed. No pleural swellings or keels. Telson densely setose; the long epiproct rounded at the apex which is curved notably down. Legs long and slender, only at the anterior body end they are a little shorter and enlarged, without peculiarities

Gonopod aperture transversely broad-oval. Gonopods (fig. 1: 3-5) with quite globose coxites fused medially. No traces of both the coxal horns and seminal groove. The telopodite falcate, elongated at the setose prefemoral portion that forms a right angle with the acropodite. The latter distally divided into two branches, the dorsal of which $(h b)$, membranous and flattened, is short, and the ventral one longer, provided with a tiny inner projection at the very thin base, distally enlargening into a rounded outer lobe $(o b)$ and an inner hyaline lamella 
(h) deoply dentate at the edge. The acropodites in situ held parallel.

\section{Remarks}

Judging from some morphological peculiarities (complete depigmentation, greatly elongated antennae and legs), C. inexpectatus n.sp. is a troglobite. The loss of both the seminal groove and cannulae (connected with the tiny body size and/or the troglobiose?) is a highly aberrant feature, that makes it possible to treat the new form as a Caucasian relic of somewhat dubious (most probably Ancient Mediterranean) genesis.

\section{Ratcheuma gen.n.}

Body of moderate size (ca. $1 \mathrm{~cm}$ ), of 30 segments. Antennae long and very slender. No lateral keels, but moderately developed lateral swellings. $3+3$ long acute macrochaetae on each body segment, not including the telson. Promentum present. Legs long and slender, only leg-pairs 1 and 2 somewhat reduced compared with subsequent legs.

$0^{7}$. - Leg-pairs 3 to 7 enlarged, without tarsal papillae. Pairs 10 and 11 with coxal glands; leg-pair 11 without coxal horns. Anterior gonopods rather short, of complex configuration: with a well developed antero-medial sternal sack (asp); with a hinder pair of parabasal long and wide flagelloid projections $(p)$; without clear "telopodites" (lateral branches); with a pair of hind basal seminal canals. Posterior gonopods consist of nearly independent coxites dividing into an inner (i) and outer $(k)$ branch; telopodites absolutely reduced; no podosternite.

Type species: Ratcheuma excorne sp.n.

Ratcheuma n.g. differs from the rest of the family Antroleucosomatidae, to which it is ascribed, first of all by the presence of prominent flagelloids on the anterior gonopods and by the lack of coxal horns on the male leg-pair 11. The first peculiarity resembles the genus Antroleucosoma Verh., with two species from Romania (s. Tabacaru, 1967), but the new form has much longer flagelloids "telopodites» unclearly split from the central part, well developed sternal sack, as far as the anterior gonopods are concerned. The two latter morphological characters resemble the monotypic genus Adshardicus Gol. from Transcaucasia (Golovatch, 1981), but both genera are as well distinguishable by the loss of the posterior gonopods' telopodites, considerably shorter anterior gonopods, \&c., in the new form. 


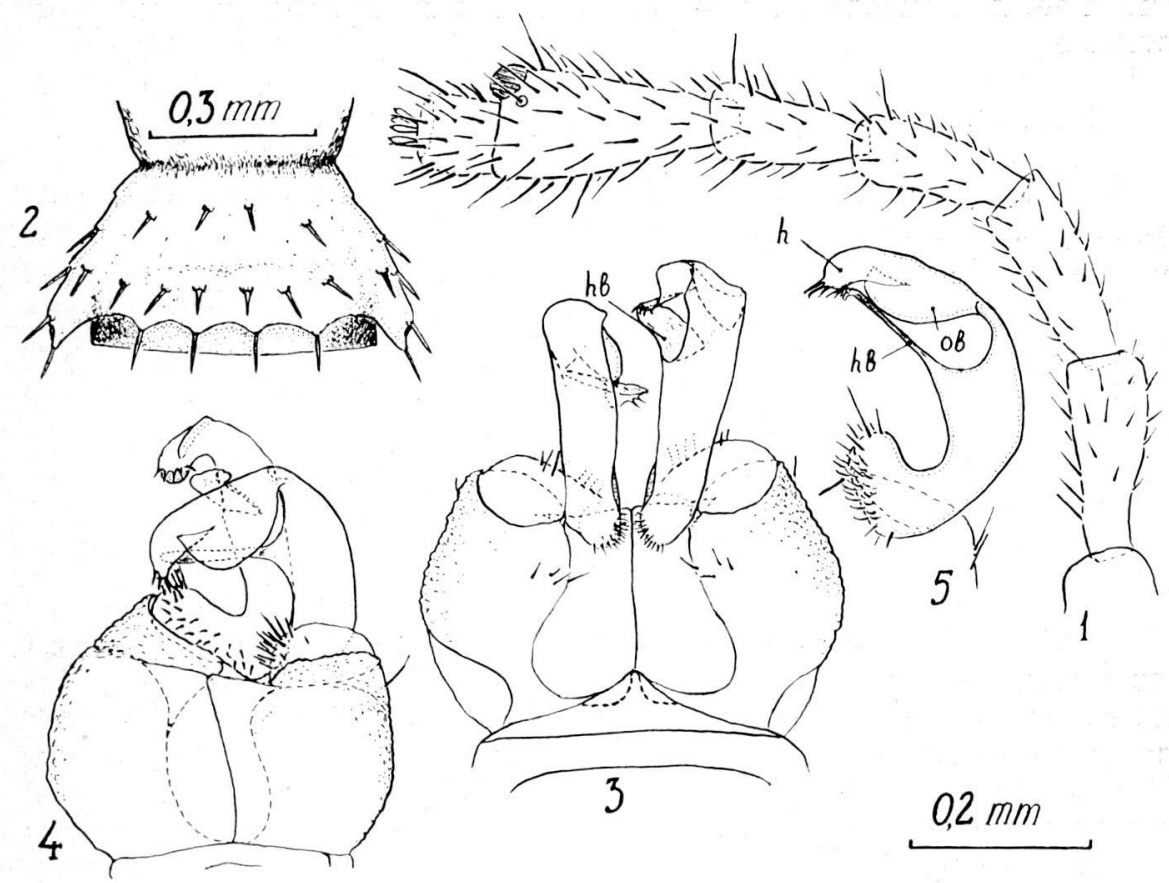

Fig. 1 - Caucasodesmus inexpectatus n.g., n.sp., $\varnothing^{\top} \overbrace{}^{-}$, paratypes: 1 - antenna, 2 - 10th body tergite (from above), 3 - gonopods (frontal view), 4 - the same (semi-lateral view), 5 - right gonopod (mesal view); $h b$ - dorsal branch, ob - outer lobe, $h$ - inner hyaline lamella.

Ratcheuma excorne sp.n.

\section{Material}

Caucasus, W Georgia, Racha Mountain Ridge, Ambrolauri district, Cave Nikortsminda near the village Nikortsminda: $10^{\pi}$ (holotype $\rho$ 1526), 1 juv. - 25 VIII 1966, leg. R.A. Djanashvili; 3 $0^{\star} ठ^{\star}, 2$ 우 우 - 15. XI 1972, leg. S. I. Ljovuschkin.

Both males and females up to $11 \mathrm{~mm}$ long, $1.0 \mathrm{~mm}$ wide. 30 body segments. Body and legs whitish. Occipital suture well developed. Labrum with 3 medial teeth at the anterior margin. Around a dozen black ocelli in a formless eye field from each side of the head. Cheeks very convex, pubescent. Gnathochila- 
rium with a promentum, stipes densely setose, lingual lamellae with 6 setae apiece. Antennae very long and slender; length width ratios of each of the articles $2,3,4,5,6$ and 7 are 1.7, 5.3 $2.0,3.8,0.7,1.4$, respectively; length ratios of the same articles are $1.8,4.8,2.3,3.8,1.0,1.5$, respectively. $3+3$ tergal macrochaetae on every body ring, excluding the telson. Dorsal axial suture well developed. Lateral keels absent; instead there are rather small lateral swellings gradually reducing to the posterior body end and disappearing from the segments 26 or 27. Macrochaetae flattened and apically acute, as long as $m-M$. Chaetotaxy formula of a mid-body segment as follows:

$$
\frac{a-p}{p-m}=\frac{1}{1.5} ; \frac{m-p}{M-m}=\frac{1}{1.5} \text {, angle ca. } 110^{\circ},
$$

where $a$ is the antero-lateral, $\mathrm{p}$ is the postero-lateral, $m$ is the medial macrochetae, and $M$ is the axial suture.

$\sigma^{7}$. - Frons somewhat flattened. Leg-pairs 3, 4, and especially 7 considerably crassate (fig. 2; 2), whereas pairs 5 and 6 enlarged quite moderately (fig. $2 ; 1$ ). The prefemora with a small outer projection at the base apiece. Leg-pairs 10 and 11 with coxal glands, the 10th (fig. 2; 4) a little enlarged compared with mid-body legs, with coxal spines, and the 11th (fig. 2; 3) normal, without any modifications on the coxae. No tarsal papillae.

Anterior gonopods massive (fig. 2; 5, 6), rather short; with quite a big antero-medial sternal sack ( $a s p$ ) covered with small dense spines; with complex membraneous disto-lateral laminae; with large flattened and bent caudal paramedial apical processes ( $\mathrm{mp})$; with a large medial membraneous lamella $(\mathrm{ml})$; with small antero-lateral fingers $(l)$; with a pair of large long broad parabasal flagelloid projections $(p)$ situated in corresponding depressings; basally with a pair of seminal canals $(s g)$; without clear «telopodites». Posterior gonopods (fig. 2, 7) with a large platelike sternite (st), without a sign of telopodites, anteriorly with a paramedial pair of gland canals (sr). Coxae split into two branches, a sack-shaped membraneous inner one (i) provided with a ventral papillar field apiece and a higher outer one $(k)$, well sclerotized and horn-like.

우. - Frons slightly convex. Legs without peculiarities. Vulvae not removed.

\section{Remarks}

Judging from the presence of quite a number of well pigmented ocelli, $R$. exaorne n.sp. seems to be no more than troglophilic, this view being supported by the finds of a trogloxene 


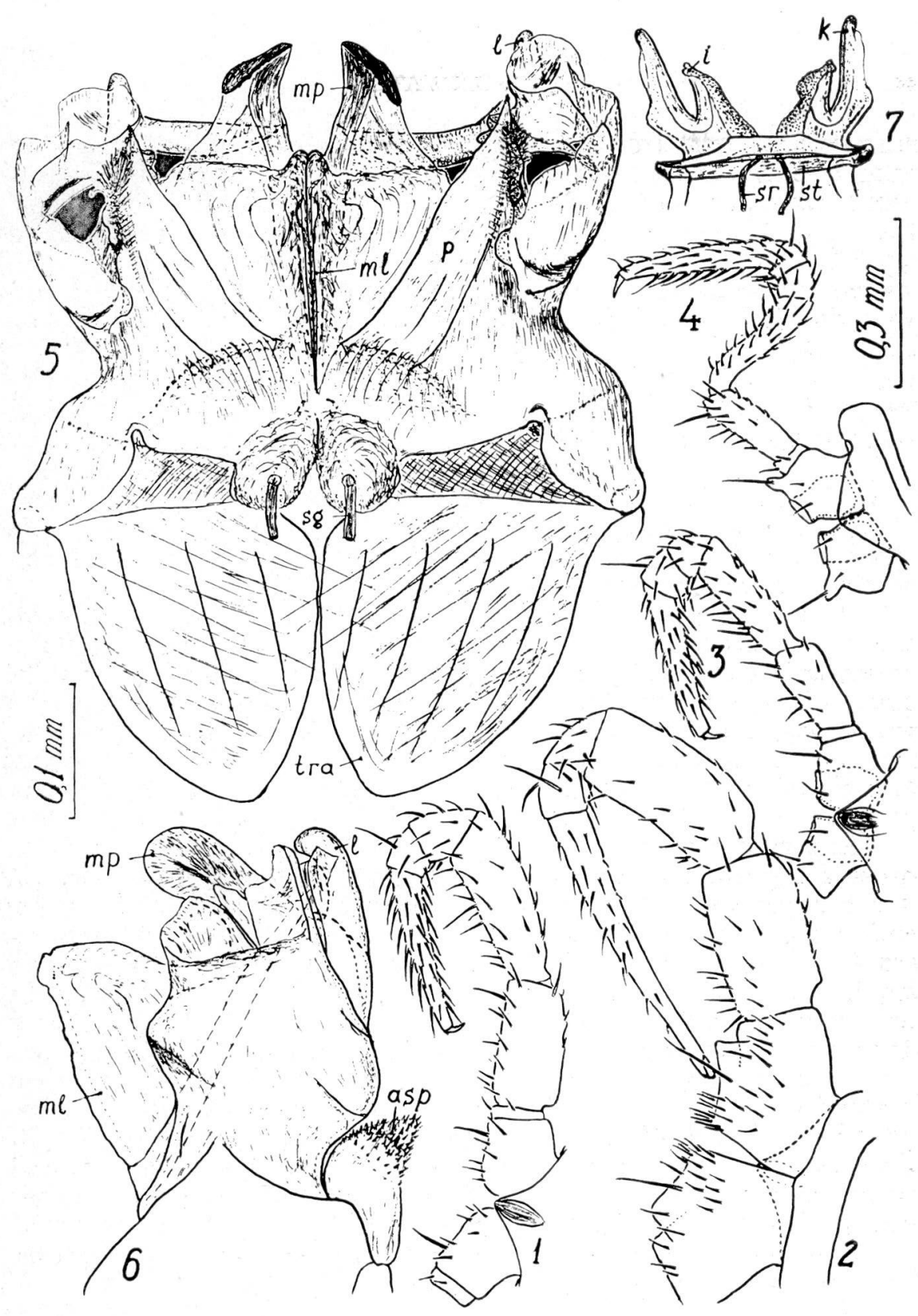

Fig. 2 - Ratcheuma excorne n.g., n.sp., $\sigma^{\star} \sigma^{\star}$, paratypes: 1 - leg-pair 6 (frontal view), 2 - leg-pair 7 (caudal view), 3 - leg-pair 11, 4 - leg-pair 10, 5 - anterior gonopods (caudal view), 6 - the same (lateral view), 7 posterior gonopods (frontal view); asp - antero-medial sternal sack, $m p$ - apical paramedial processes, $m l$ - medial lamella, $l$ - anterolateral fingers, $p$ - flagelloid projections, sg - seminal canals, tra tracheal apodemes, st - sternum, $s r$ - glandular canals, $i$ - inner branch, $k$ - outer branch. 
pigmented Cylindroiulus sp. (Julidae) and trogloxene or troglophilic Brachydesmus ferrugineus Lohm. (Polydesmidae) in the same cave ( $\mathrm{Nr} 36$, fig. 3).

\section{A REVIEW OF THE WEST CAUCASIAN CAVERNICOLOUS MILLIPEDE FAUNA}

At present, if literature data are also considered, millipedes are known from more than forty caves and grottos of the West Caucasus, most of them being situated in western Transcaucasia within three biospeleological regions: northwestern (the Black Sea coast NW of Gagra - Gudauta), Abkhazian (the Black Sea coast from Gagra-Gudauta to Ochamchiré) and West Georgian ones (environs of Kutaisi and Tshaltubo and Racha Mts.). The biospeleological division of western Transcaucasia in general corresponds to karstological and hydrographical ones, being supported by the presence of peculiar faunal complexes in each of the regions (Birstein, Ljovuschkin, 1967).

Up to now, due to scanty data on both taxonomy and faunistics of Caucasian cave-dwelling millipedes, the Diplopoda have been applied for biogeographical reconstructions and characteristics of relations with caves to a limited extent. Even now such data are still far from complete.

When examining the diplopod cavernicolous fauna of the western Caucasus on the whole, one may notice that it is surprisingly monotonous, especially at generic and/or familial levels. Thus, the genera Archileucogeorgia, Trachysphaera, the family Antroleucosomatidae turn out to be quite commonplace there, but the majority if not all of the species from these taxa are apparently no more than troglophilic.

The genus Archileucogeorgia (Julidae) is very widespread in Georgian caves. In Abkhazia, species of this genus occur in caves Kelasuri (= Aleksandrovskaya) ( $\mathrm{Nr}$ 15, fig. 3) nearby Sukhumi (locus typicus! for A. abchasica Lohm. and $A$. satunini Lohm. - Lohmander, 1936) and Abrskili (= Ablaskiri, Chilovskaya, Achszé-Tyz-Gua) ( $\mathrm{Nr} 18$ ) nearby Ochamchiré ( $A$. abchasica Lohm.- Birstein, 1950; Kobakhidze, 1965). In Imeretia and Racha, Archileucogeorgia spp. are known from caves Sakadjia ( $\mathrm{Nr}$ 21), Chuneshi ( $\mathrm{Nr} 22)$, Belaya (= Tskhaltubskaya Stalaktitovaya) ( $\mathrm{Nr} 25$ ), Sataplia I, II and IV ( $\mathrm{Nr} 26)$, Tsikhé (= Zedakvilishori) ( $\mathrm{Nr}$ 27) in the environs of Kutaisi and Tskaltubo, Imeretia, as well as in caves Tkibula-Dzevrula ( $\mathrm{Nr}$ 30) nearby Tkibuli, Tvishi ( $\mathrm{Nr}$ 31) near Tsageri, Tsakhi ( $\mathrm{Nr}$ 32) near Ambrolauri and Bnelakldé (Nr 33) in the environs of Chiatura, Racha. Quite a surprising discovery of an Archileuco- 


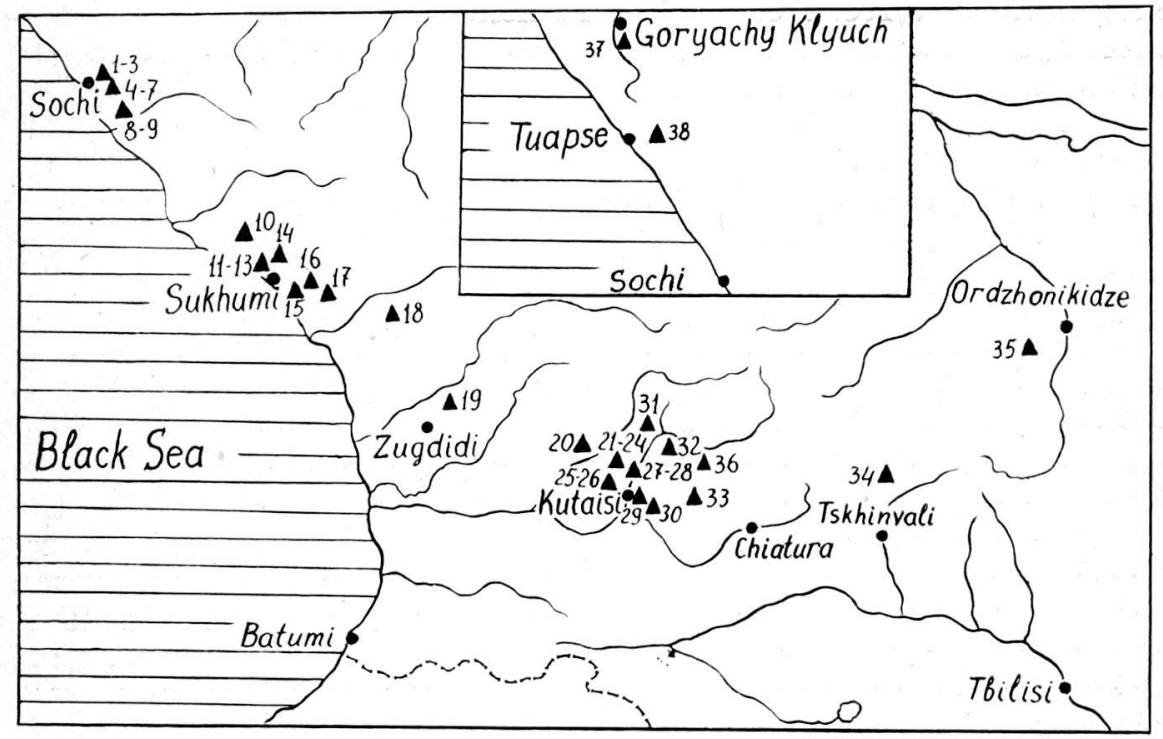

Fig. 3 - Distribution of cave-dwelling millipedes of the western Caucasus. Caves: 1 - Partizanskaya, 2 - Pionerskaya, 3 - Bozhyey Materi (Our Lady), 4 - Dolgaya, 5 - Vorontsovskaya, 6 - Labirintovaya, 7 - Podparapetnaya, 8 - Nizhne-Kazachebrodskaya, 9 - Verkhne-Kazachebrodskaya, 10 - Tarkili, 11 - Adzaba, 12 - Sobachya, 13 - "Zmeyka» 14 - Kazandji, 15 - Kelasuri, 16 - Mikhaylovskaya, 17 - Tsebelda, 18 - Abrskili, 19 - Inguri, 20 - Motena, 21 - Sakadjia, 22 - Chuneshi, 23 - Orpiri I and II, 24 - Solkota, 25 - Belaya, 26 - Sataplia I, II and IV, 27 - Tsikhé, 28 - Gliana, 29 - Riongesovskaya, 30 - Tkibula-Dzevrula, 31 - Tvishi, 32 - Tsakhi, 33 - Bnelakldé, 34 - Kudaro, 35 - Nyvdjinlagat, 36 - Nikortsminda, 37 - Fanagoriyskaya, 38 - Psebé.

georgia sp. in the Cave Fanagoriyskaya (Nr 37) in Ciscaucasia is indicative of the relationship not with the northwestern, but with the Abkhazian and/or West Georgian biospeleological regions (Birstein, Ljovuschkin, 1967). All or nearly all cavernicolous Archileucogeorgia spp. of West Caucasus are presumed to be troglophilic; thus, both $A$. abchasica and $A$. satunini were described from one and the same cave which argues against their troglobiose; besides, A. satunini was found later in forest litter nearby Tsebelda, Abkhazia (det. C. Dziadosz, the collection of the Zoological Institute of the USSR Academy of Sciences, Leningrad), and another species occurred in forests of the Caucasian State Reservation, North Caucasus (Ghilarov, 1972).

Species of the genus Trachysphaera (Glomeridae) from Caucasian caves are better known (Golovatch, 1976). Within the northwestern region, in the environs of Sochi, T.minuta 
was described from caves Partizanskaya (= Smaller Vorontsovskaya) ( $\mathrm{Nr}$ 1) and Nizhne-Kazachebrodskaya (= NizhneMzymtinskaya) (Nr 8) (locus typicus!); in the West Georgian region, in Imeretia, T. fragilis is quite common in caves Motena ( $\mathrm{Nr} 20)$ in the environs of Gegechkori, Orpiri I and II ( $\mathrm{Nr} 23$ ), Solkota (Nr 24), Sataplia I, II and IV ( Nr 26) and Gliana ( Nr 28) (locus typicus!) near Kutaisi and Tskhaltubo. T. orientalis Gol. is known only from the Cave Bnelakldé ( $\mathrm{Nr} 33$ ) (locus typicus!) and just at its entrance, Racha; a $T$. aff. orientalis (probably a new form) was discovered in the Cave Tsakhi ( $\mathrm{Nr} 32$ ), Racha. The Cave Orpiri I (Nr 23) is both the only locality and locus typicus! for T. solida Gol. All the cave-dwelling Trachysphaera spp. are obviously no more than troglophilic; this is so far clear for $T$. orientalis only (Golovatch, 1976).

Cavernicolous Antroleucosomatidae, being quite commonplace in western Transcaucasia, are taxonomically very poorly worked out. Caucaseuma lohmanderi Str. is known from caves Partizanskaya ( $\mathrm{Nr}$ 1), Bozhyey Materi (= Our Lady Nr 3), Dolgaya ( $\mathrm{Nr} 4)$, Vorontsovskaya (= Larger Vorontsovskaya) $(\mathrm{Nr}$ 5) (Strasser, 1970), Labirintovaya ( $\mathrm{Nr} 6)$, Podparapetnaya (= Muzeynaya I) ( $\mathrm{Nr} 7$ ) (1) and Nizhne-Kazachebrodskaya ( $\mathrm{Nr} 8$ ), all near Sochi. Ratcheuma excorne n.g., n.sp. occurs in the Cave Nikortsminda ( $\mathrm{Nr}$ 36) (locus typicus!), Racha. Still not processed antroleucosomatids are known from caves Tarkili ( = Tarkiladze) ( $\mathrm{Nr}$ 10) near Gudauta, Adzaba ( $\mathrm{Nr} 11)$, Sobachya (= Verkhne-Esherskaya) (Nr 12), "Zmeyka" (Nr 13), Kazandji (= Ali) near Sukhumi, Tsebelda ( $\mathrm{Nr}$ 17) near Gulripsha, all in Abkhazia. All the antroleucosomatids from western Caucasian caves are apparently troglophilic, since they all have quite numerous and pigmented ocelli.

In zoogeographical aspect, these predominant troglophilic groups, Archileucogeorgia, Trachysphaera and Antroleucosomatidae, display clear Ancient Mediterranean faunal connections. Another troglophilic form to be mentioned is Nopoiulus kochii (Gerv.) (Blaniulidae) large populations of which inhabit caves Nizhne-Kazachebrodskaya ( $\mathrm{Nr} 8$ ) and Verkhne-Kazachebrodskaya (=Verkhne-Mzymtinskaya) ( $\mathrm{Nr}$ 9) in Sochi district. As trogloxene or troglophilic at the best should be considered Pachyiulus foetidissimus (Mur.) (Pachyiulinae) found in

(1) K. Strasser (1970) described two new diplopods, C. lohmanderi and Brachydesmus ferrugineus exiguus, and designed the Cave "Baribana" near the village Ilarionovka, environs of Sochi, as the locus typicus! for both of them As soon as there is no cave or grotto with such a name not only at Ilarionovka, but near Sochi on the whole, it seems that the "Baribana" is in fact identical with the Cave Podparapetnaya ( $\mathrm{Nr} 7)$ which indeed is situated nearby Ilarionovka and contains a large population of C. lohmanderi (author's observations failed, however, to revel a Brachydesmus there). 
a grotto near Novorossiysk and in the Cave Pionerskaya ( $\mathrm{Nr} 2)$ near Sochì; ? Hyleoglomeris sp. (Glomeridae) from a tectonic cave ( $\mathrm{Nr}$ 38) in the upper reaches of the Psebé River, Tuapse area; Nopoiulus (Paranopoiulus) spp. (Blaniulidae) from the Cave Kelasuri (Nr 15) nearby Sukhumi, Abkhazia, and from a number of North Caucasian caves (det. H. Enghoff); Chromatoiulus dioscoriadis (Lign.) (Julidae) from the Cave Mikhaylovskaya (Nr 16) near Sukhumi (Lohmander, 1936; Kobakhidze, 1965); ? Choneiulus sp. (Blaniulidae) from the Cave Inguri (Nr 19) discovered and destroyed during the building of the Inguri hydroelectric power station, Zugdidi area, Mingrelia, Georgia; Brachydesmus kalischewskyi Lign. (Polydesmidae) from the Cave Kudaro ( $\mathrm{Nr}$ 34) near Djava, South Osetia, Georgia.

True troglobites of the Caucasus are represented by highly local and relic forms. Thus, quite an aberrant endemic, Caucasodesmus n.g. (Macrosternodesmidae), with the only C. inexpectatus n.sp., is known just from the Cave Nyvdjinlagat $(\mathrm{Nr}$ 35), North Osetia.

The two hitherto known species of the Caucasian endemic genus Leucogeorgia (Julidae) are restricted to one cave each: L. longipes Verh. to the Cave Rion (= Riongesovskaya) (Nr 29) near Kutaisi, Imeretia (Verhoeff, 1930), discovered and destroyed during the building of the Rion hydroelectric power station, and $L$. rediviva Gol. to the Cave Sobachya ( $\mathrm{Nr} 12)$ near Sukhumi, Abkhazia (Golovatch, 1983). Therefore, there are faunal connections between troglobites of the West Georgian and Abkhazian biospeleological regions. On the whole, the genus Leucogeorgia is very closely related to if not a derivative of another Caucasian endemic, namely the genus Archileucogeorgia. The tribe Leucogeorgiini is known to include five small relic genera distributed, aside from the Caucasus, in Greece, Sardinia and Spain (Strasser, 1976).

The only hitherto known Caucasian species of the Balkan genus Typhloglomeris (Glomeridellidae), namely $T$. caucasica Gol. from caves Partizanskaya ( $\mathrm{Nr} 1$ ), Bozhyey Materi ( $\mathrm{Nr} 3$ ), Dolgaya ( $\mathrm{Nr} 4$ ) (locus typicus!), Vorontsovskaya ( $\mathrm{Nr} 5$ ), all near Sochi, is another probable troglobite expressing, along with numerous other cave-dwelling Caucasian invertebrates (Birstein, Ljovuschkin, 1967), distinct Ancient Mediterranean zoogeographical connections (Golovatch, 1975).

Morphologically, adaptations of the diplopod troglobites of the Caucasus to cavernicolous mode of life display in certain aberrations (i.e. very peculiar mouthparts of Leucogeorgia or quite a strange loss of both cannulae and seminal groove of gonopods in Caucasodesmus n.g.), very long and slender antennae and legs, complete or notable reduction of the number of ocelli and their depigmentation, decoloration of body teguments. 


\section{ACKNOWLEDGEMENTS}

I am extremely thankful to Prof. R.L. Hoffman of Radford, Va., USA, for his most valuable comments on the taxonomy of Caucasodesmus n.g. Also, I wish to express my sincerest gratitude to Mrs. N.T. Zalesskaja of Moscow, USSR, for her permanent interest to the work and encouragement.

\section{RESUME}

Deux nouveaux genres et espèces de Diplopodes des grottes du Caucase sont décrits: Caucasodesmus inexpectatus n.g., n.sp. (la famille des Macrosternodesmidae), troglobie d'une grotte d'Ossétie-Nord (Caucase du Nord), et Ratcheuma excorne n.g., n.sp. (la famille des Antroleucosomatidae), troglophile d'une grotte de Ratcha (Géorgie, Transcaucasie). Les Diplopodes de la faune cavernicole du Caucase occidental sont traités, par rapport à lour distribution, aux relations avec les grottes et aux connections zoogéographiques.

\section{REFERENCES}

BIRSTEIN, J.A. 1950. Cavernicolous fauna of western Transcaucasia (in Russian). Zool. Zhurnal 29 (4): 354-366.

BIRSTEIN, J.A., S.I. LJOVUSCHKIN, 1967. Some results and problems of study of the subterranean fauna of the USSR (in Russian). Ibidem 46 (10) . 1509-1535.

CARL, J. 1926. Diplopoden von Neu-Caledonien und den Loyalty-Inseln, in: Nova Caledonia, 4A, Lief. 3, München: 369-462.

GHILAROV, M.S. 1972. Terricolous fauna of brown soils of the Caucasus Major (in Russian), p. 37-38. In: Problems of soil zoology (materials of the 4th All-Union conference of pedozoologists in Baku, 1972), Nauka Publ. House, Moscow.

GOLOVATCH, S.I. 1975. Two new for the USSR fauna genera of Oniscomorpha (Diplopoda) found in Transcaucasia and their zoogeographical connections (in Russian). Zool. Zhurnal 54 (10): 1566-1571.

GOLOVATCH, S.I. 1976. A description of new species of Trachysphaera (Oniscomorpha; Diplopoda) from caves of western Transcaucasia, with remarks on T. rotundata (Lignau) 1911 (in Russian). Bull. Soc. Natural. Moscou, sect. biol., 81 (5): 30-43.

GOLOVATCH, S.I. 1981. Some new forms of millipedes (Diplopoda) from the Caucasus. Ann. Zool. PAN 36 (5):105-116.

GOLOVATCH, S.I. 1983. Une nouvelle espèce cavernicole du genre Leucogeorgia Verh. de la Transcaucasie (Diplopoda, Julidae). Fragm. Entomol., 17 (1): 47-50.

HOFFMAN, R.L. 1979. Classification of the Diplopoda. Muséum d'Histoire naturelle, Genève, $237 \mathrm{p}$.

KOBAKHIDZE, D.N. 1965. A list of millipedes (Diplopoda) of the Georgian SSR (in Russian). Fragm. faun. PAN 11 (21): 389-398.

LOHMANDER, H. 1936. Ueber die Diplopoden des Kaukasusgebietes. Göteborgs K. Vetensk. - o. Vitt.-Samh. Handl., 5, Följden, 5B (1). 1-196.

STRASSER, K. 1970. Ueber einige Diplopoden aus dem westlichen Kaukasus. Rev. Suisse Zool. 77 (1):199-205.

STRASSER, K. 1976. Ueber Diplopoda-Chilognatha Griechenlands, II. Ibidem 83 (3): $579-645$.

TABACARU, I. 1967. Beiträge zur Kenntnis der cavernicolen Antroleucosomiden (Diplopoda, Ascospermophora). Int. J. Speleol. 3:1-31.

VERHOEFF, K.W. 1930. Eine neue cavernicole Symphyognathen-Gattung aus Georgien, Transcaucasien. Mitt. ü. Höhlen- u. Karstforsch., Jg. 1930, 2, Berlin:1-7. 